УДК 343.9

DOI: $10.17223 / 22253513 / 38 / 9$

\title{
О.В. Филиппова
}

\section{КРИМИНОЛОГИЧЕСКАЯ ХАРАКТЕРИСТИКА РЕЦИДИВНОЙ ПРЕСТУПНОСТИ}

\begin{abstract}
Раскрыто уголовно-правовое и криминологическое понятие реиидивной преступности. Проанализированы статистические данные о состоянии преступности, судимости и составе осужденных к лишению свободы в период с 2006 по 2018 г., обозначены основные количественные и качественные показатели рецидивной преступности, выявлены тенденции ее развития. Показаны региональные особенности рецидивной преступности. Дана характеристика динамики выявленных лии, ранее совершавших преступления, в числе которых значительную долю составляют те, кто за ранее совершенные преступления освобождался от уголовной ответственности по нереабилитирующим обстоятельствам.

Ключевые слова: рецицив, преступность, криминологическая характеристика.
\end{abstract}

Характерной чертой российской преступности последних лет является высокий уровень рецидива. По данным Главного информационноаналитического центра МВД России, в 2018 г. 58,3\% всех преступлений совершено лицами, ранее совершавшими преступления [1]. Рецидив преступлений - показатель несовершенства уголовного законодательства, неэффективности правоприменительной практики (назначения и исполнения наказаний, освобождения от уголовной ответственности и наказания) и профилактической деятельности различных субъектов.

Рецидивная преступность, как и преступность в целом, есть социальноправовое явление. Социальная природа преступности означает, что она обусловлена явлениями и процессами, происходящими в обществе, которые носят преимущественно социальный характер [2. С. 62]. Правовой характер преступности обусловлен тем, что деяния, составляющие содержание преступности, определены уголовным законом. Так, уголовным законом (ст. 18 УК РФ) предусмотрено, что рецидивом преступлений признается совершение умышленного преступления лицом, имеющим судимость за ранее совершенное умышленное преступление. При признании рецидива не учитываются судимости: за умышленные преступления небольшой тяжести; за преступления, совершенные лицом в возрасте до 18 лет; за преступления, осуждение за которые признавалось условным либо по которым предоставлялась отсрочка исполнения приговора, если условное осуждение или отсрочка исполнения приговора не отменялись и лицо не направлялось для отбывания наказания в места лишения свободы, а также судимости, снятые или погашенные в порядке, предусмотренном ст. 86 УК РФ. 
Уголовно-правовое определение рецидива существенно ограничивает круг уголовно наказуемых деяний, которые могут быть признаны рецидивом. Так, за его пределами остаются случаи совершения неосторожных преступлений, а также совершения преступлений лицами, у которых судимость за предыдущее преступление снята и погашена, и др.

Криминологическое понятие рецидивной преступности охватывает все случаи совершения преступлений лицами, ранее совершавшими преступления независимо от наличия (отсутствия) судимости за прежнее преступление, формы вины и категории предшествующего и последующего преступления, возраста, в котором лицо совершило преступление, меры уголовноправового воздействия за ранее совершенное преступление. При этом в соответствии с Приказом Генеральной прокуратуры РФ, МВД РФ, МЧС РФ, Минюста РФ, ФСБ РФ, Минэкономразвития РФ и Федеральной службы РФ по контролю за оборотом наркотиков от 29.12.2005 № 39/1070/1021/253/ 780/353/399 «О едином учете преступлений» лицо считается ранее совершившим преступление, если оно за ранее совершенное им преступление привлекалось к уголовной ответственности (уголовное дело направлялось в суд либо прекращалось по нереабилитирующим основаниям) [3].

Криминологическое изучение рецидивной преступности направлено не на простое признание в действиях лица рецидива, а на выявление причин возвращения лица к преступной деятельности после применения к нему мер уголовно-правового воздействия за предыдущее преступление, в целях разработки мер его предупреждения. Потому криминологическое понятие рецидива значительно шире уголовно-правового.

Криминологическая характеристика рецидивной преступности включает количественный и качественный анализ совокупности преступлений, совершенных лицами, ранее совершавшими преступления, после применения к ним мер уголовно-правового воздействия за предыдущие преступления, а также совокупности самих этих лиц. Такое исследование позволит дать оценку масштабам данного явления, установить закономерности его развития, смоделировать и спрогнозировать его показатели в будущем.

О состоянии рецидивной преступности можно судить на основе анализа статистической отчетности органов внутренних дел, прокуратуры, Судебного департамента при Верховном Суде РФ по таким группам показателей, как количество зарегистрированных и расследованных преступлений, количество и состав выявленных лиц, совершивших преступления, количество и состав осужденных.

Основными криминологическими показателями преступности являются состояние (уровень), структура и динамика. Состояние рецидивной преступности представляет собой зарегистрированное количество преступлений, совершенных лицами, ранее совершавшими преступления, и число лиц, ранее совершавших преступления, в определенный период времени на конкретной территории. Уровень, или коэффициент, рецидивной преступности выражается в соотношении количества рецидивных преступлений, совершенных на территории страны в целом либо отдельных ее регионов, 
и населения соответствующей территории в расчете на 100 тыс. человек. Данный показатель некоторые авторы называют коэффициентом рецидивной пораженности [4. С. 82].

Структура рецидивной преступности как соотношение входящих в ее состав групп (видов) повторных преступлений и лиц, их совершивших, может быть построена по различным основаниям: по объекту, категории первого и последующих преступлений, виду рецидива, количеству судимостей у рецидивистов, характеру мер уголовно-правового воздействия за предыдущее преступление и др.

Динамика рецидивной преступности показывает ее изменение за определенный промежуток времени на конкретной территории.

Согласно данным официальной статистики в период с 2006 по 2018 г. было зарегистрировано следующее количество преступлений, совершенных лицами, ранее совершавшими преступления: в 2006 г. - 534 283, в 2007 г. 534 072, в 2008 г. - 521 552, в 2009 г. - 531 798, в 2010 г. - 530 742, в 2011 г. 533 487, в 2012 г. -583 247, в 2013 г. - 613 779, в 2014 г. - 635 551, в 2015 г. 688 817, в 2016 г. - 674 935, в 2017 г. - 650 565, в 2018 г. - 634 027. Как видно, общей тенденцией последних лет стало увеличение абсолютного числа рецидивных преступлений, хотя в отдельные годы $(2007,2008,2010)$ отмечалось их снижение; наибольшее количество зафиксировано в 2015 г., наименьшее - в 2008 г. Темп прироста в 2018 г. по отношению к 2006 г. составил $18,6 \%$ (табл. 1).

Таблица 1

Количество зарегистрированных преступлений, преступлений, совершенных лицами, ранее совершавшими преступления, и их удельный вес с 2006 по 2018 г.

\begin{tabular}{|c|c|c|c|}
\hline Год & $\begin{array}{c}\text { Число } \\
\text { зарегистрированных } \\
\text { преступлений }\end{array}$ & $\begin{array}{c}\text { Число преступлений, } \\
\text { совершенных лицами, } \\
\text { ранее совершавшими } \\
\text { преступления }\end{array}$ & $\begin{array}{r}\text { Удельный вес преступлений, } \\
\text { совершенных лицами, ранее } \\
\text { совершавшими преступления, } \\
\text { в структуре преступности в целом }\end{array}$ \\
\hline 2006 & 3855373 & 534283 & 13,9 \\
\hline 2007 & 3582541 & 534072 & 14,9 \\
\hline 2008 & 3209862 & 521552 & 16,3 \\
\hline 2009 & 2994820 & 531798 & 20,2 \\
\hline 2010 & 2628799 & 530742 & 22,2 \\
\hline 2011 & 2404807 & 533487 & 25,3 \\
\hline 2012 & 2302168 & 583247 & 29,8 \\
\hline 2013 & 2206249 & 613779 & 28,8 \\
\hline 2014 & 2190578 & 635551 & 31,2 \\
\hline 2015 & 2388476 & 688817 & 31,6 \\
\hline 2016 & 2160063 & 674935 & 31,8 \\
\hline 2017 & 2058476 & 650565 & \\
\hline 2018 & 1991532 & 634027 & \\
\hline
\end{tabular}

В структуре общей преступности доля преступлений лиц, ранее совершавших преступления, заметно увеличилась: с 13,9\% в 2006 г. до 31,6\% в 2018 г., или в 2,3 раза (рис. 1). Данная тенденция сложилась на фоне сокращения общего числа зарегистрированных в РФ преступлений: их коли- 
чество в 2018 г. уменьшилось почти вдвое по сравнению с 2006 г. (с 3855373 в 2006 г. до 1991532 в 2018 г.). В исследуемый период тенденцию к снижению демонстрировали практически все общеуголовные преступления, составляющие основной массив российской преступности. Вместе с тем объективных предпосылок к столь положительной динамике преступности не было, потому полагаем, что такая динамика показывает повышение латентной части преступности в последние годы. Как справедливо отмечают ученые, основная доля реальной российской преступности является латентной, и регистрируется лишь незначительная часть совершенных преступлений [5. С. 153].

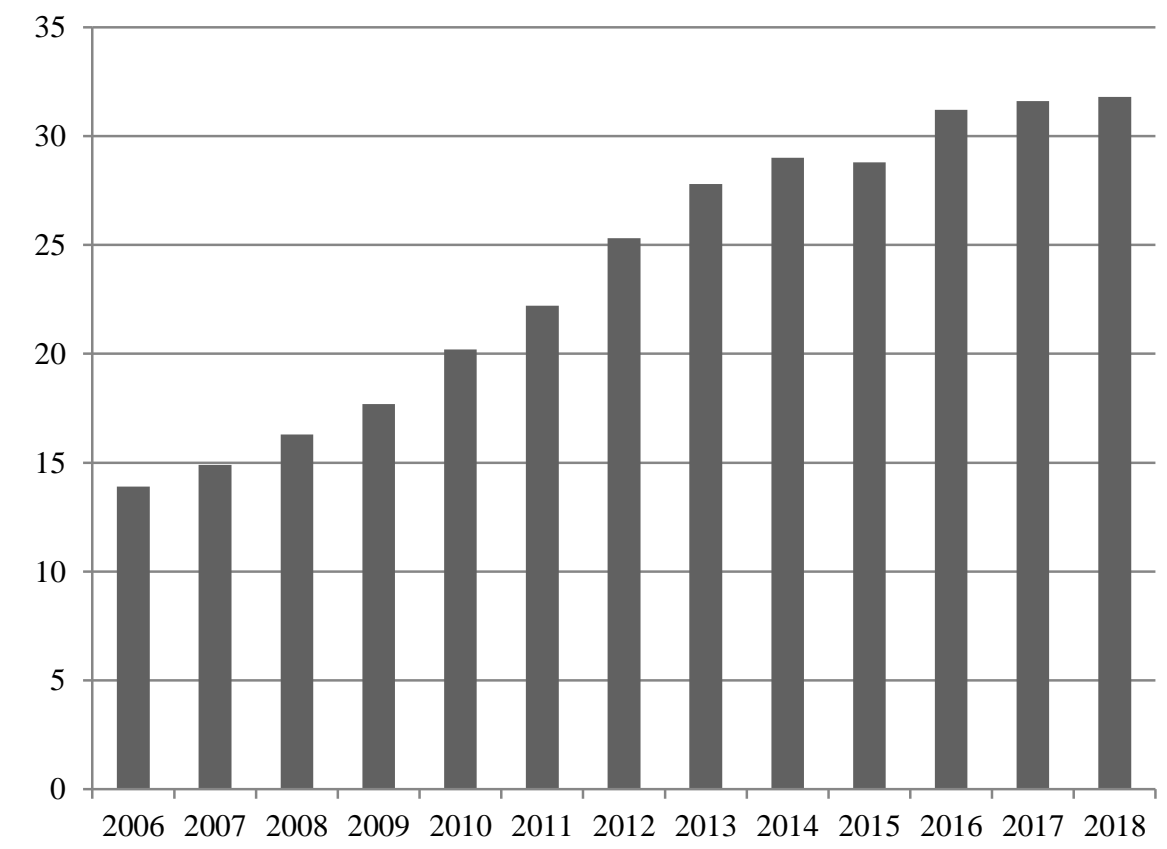

Рис. 1. Динамика удельного веса преступлений, совершенных лицами, ранее совершавшими преступления, в структуре преступности в целом с 2006 по 2018 г.

Одновременно увеличение зарегистрированного количества преступлений лиц, ранее совершавших преступления, свидетельствует о том, что для них нехарактерна высокая степень латентности и они в большем объеме (нежели общеуголовные) представлены в уголовной статистике. Последнее, на наш взгляд, связано с тем, что лица, ранее попадавшие в сферу уголовного преследования, состоят на разного рода криминалистических учетах, и при проведении розыскных мероприятий их нетрудно установить.

Статистические показатели рецидивных преступлений необходимо дополнить сведениями о лицах, их совершивших. Абсолютное число лиц, ранее совершавших преступления, в рассматриваемый период имело следующие значения: 2006 г. - 392 275, 2007 г.- 383 418, 2008 г. - 377 401, 
2009 г. - 390 549, 2010 г. - 397 403, 2011 г. - 401 894, 2012 г. - 452312 , 2013 г. - 482520,2014 г. - 510122 (50,7\%), 2015 г. - 556 914, 2016 г. 548 382, 2017 г. - 541 541, 2018 г. - 525475 (табл. 2). Несмотря на незначительные колебания в отдельные годы, в целом их количество в 2018 г. по сравнению с 2006 г. увеличилось на 25,3\%.

В это же время существенно сократилось общее количество выявленных преступников, поэтому удельный вес ранее совершавших преступления в их числе заметно увеличился: если в 2006 г. их доля составляла $28,8 \%$, то в 2018 г. - 56,4\% (темп прироста - 34\%).

Таблица 2

Количество выявленных лиц, ранее совершавших преступления, и их удельный вес в общем числе выявленных лиц, совершивших преступления с 2006 по 2018 г.

\begin{tabular}{|c|c|c|c|}
\hline Год & $\begin{array}{c}\text { Число выявленных } \\
\text { лиц, совершивших } \\
\text { преступления }\end{array}$ & $\begin{array}{c}\text { Число выявленных } \\
\text { лиц, ранее совершав- } \\
\text { ших преступления }\end{array}$ & $\begin{array}{c}\text { Удельный вес лиц, ранее со- } \\
\text { вершавших преступления, в } \\
\text { общем числе выявленных лиц, } \\
\text { совершивших преступления }\end{array}$ \\
\hline 2006 & 1360860 & 392275 & 28,8 \\
\hline 2007 & 1317582 & 383418 & 29,1 \\
\hline 2008 & 1256199 & 377401 & 30,0 \\
\hline 2009 & 1219789 & 390549 & 32,0 \\
\hline 2010 & 1111145 & 397403 & 35,8 \\
\hline 2011 & 1041340 & 401894 & 38,6 \\
\hline 2012 & 1010938 & 452312 & 44,7 \\
\hline 2013 & 1012563 & 482520 & 50,6 \\
\hline 2014 & 1006003 & 510122 & 51,8 \\
\hline 2015 & 1075333 & 556914 & 53,9 \\
\hline 2016 & 1015875 & 548382 & 56,0 \\
\hline 2017 & 967103 & 541541 & \\
\hline 2018 & 931107 & 525475 & \\
\hline
\end{tabular}

В совокупности лиц, ранее совершавших преступления, имела тенденцию к снижению доля ранее судимых: с 80,6\% в 2006 г. до 51,6\% в 2018 г. (табл. 3). Учитывая, что к «лицам, ранее совершавшим преступления» относятся как ранее судимые лица, так и те, кто освобождался от уголовной ответственности по нереабилитирующим основаниям, можно сделать вывод об увеличении численности последних, т.е. тех, кто за предыдущее преступление не был осужден, а освобожден от уголовной ответственности по нереабилирующим основаниям.

Такое положение обусловлено гуманизацией уголовного законодательства, выразившейся в том числе в расширении видов освобождения от уголовной ответственности, смягчении его оснований. Данная политика способствовала тому, что значительное число лиц, совершивших преступления, сегодня освобождается от уголовной ответственности. К примеру, в 2018 г. в суды были направлены уголовные дела в отношении 858015 человек, в отношении 154755 человек дела судами прекращены (в том числе в связи с примирением с потерпевшим - 125 873, назначением судебного штрафа - 33 329, деятельным раскаянием - 11 991, применением принудитель- 
ных мер воспитательного воздействия - 2 295, отменой или изменением уголовного закона - 143). То есть освобождение от уголовной ответственности в современной судебной практике - явление массовое [6. С. 188].

Таблица 3

Количество ранее судимых лиц, совершивших преступления, и их удельный вес в общем числе лиц, ранее совершавших преступления с 2006 по 2018 г.

\begin{tabular}{|c|c|c|c|}
\hline Год & $\begin{array}{c}\text { Число выявленных } \\
\text { лиц, ранее совершав- } \\
\text { ших преступления }\end{array}$ & $\begin{array}{c}\text { Число выявленных ранее } \\
\text { судимых лиц, совершив- } \\
\text { ших преступления }\end{array}$ & $\begin{array}{c}\text { Удельный вес ранее суди- } \\
\text { мых в общем числе лиц, } \\
\text { ранее совершавших пре- } \\
\text { ступления }\end{array}$ \\
\hline 2006 & 392275 & 316034 & 80,6 \\
\hline 2007 & 383418 & 306105 & 79,8 \\
\hline 2008 & 377401 & 299521 & 79,4 \\
\hline 2009 & 390549 & 291285 & 74,6 \\
\hline 2010 & 397403 & 294167 & 74,0 \\
\hline 2011 & 401894 & 299005 & 72,3 \\
\hline 2012 & 452312 & 326894 & 66,7 \\
\hline 2013 & 482520 & 322029 & 60,5 \\
\hline 2014 & 510122 & 308616 & 54,5 \\
\hline 2015 & 556914 & 303494 & 49,8 \\
\hline 2016 & 548382 & 272967 & 50,5 \\
\hline 2017 & 541541 & 273379 & 51,6 \\
\hline 2018 & 525475 & 270988 & \\
\hline
\end{tabular}

Следует напомнить, что уголовно-правовой институт освобождения от уголовной ответственности, имея превентивные цели, призван стимулировать позитивное поведение виновного после совершения преступления. Однако учащение фактов повторного совершения лицами преступлений после освобождения от уголовной ответственности за ранее совершенное преступление не позволяет говорить о достижении данных целей. Более того, динамика выявленных лиц, совершивших преступление, свидетельствует о том, что широкое применение освобождения от уголовной ответственности отрицательно сказывается на развитии рецидивной преступности.

Для сопоставления количественных характеристик рецидивной преступности и сравнения ее уровня в регионах страны обратимся к относительным показателям, коэффициентам преступности. Согласно имеющимся данным, коэффициент рецидивной преступности в Российской Федерации в исследуемый период колебался в пределах от 367,3 (2008) до 470,9 (2015) на 100 тыс. чел. При этом если в начале исследуемого периода, с 2006 по 2009 г., уровень рецидива отличался некоторой стабильностью, то в 20102015 гг. наметился его рост, а в 2016-2018 гг. - снижение (табл. 4). Темп прироста рецидивной преступности в 2018 г. по отношению к 2006 г. составил $15,3 \%$. Таким образом, динамика коэффициента вполне соответствовала динамике абсолютных показателей рецидивной преступности.

Распределение рецидивной преступности в различных регионах страны неодинаково. Как показал статистический анализ, в Центральном, Северо- 
Западном, Северо-Кавказском, Южном федеральных округах уровень рецидива ниже, чем в среднем по стране, в Приволжском, Уральском, Сибирском, Дальневосточном - выше (табл. 5).

Таблица 4

Коэффициент рецидивной преступности в Российской Федерации с 2006 по 2018 г.

\begin{tabular}{|c|c|}
\hline Год & $\begin{array}{c}\text { Коэффициент рецидивной преступности } \\
\text { на 100 тыс. чел. населения }\end{array}$ \\
\hline 2006 & 374,3 \\
\hline 2007 & 375,5 \\
\hline 2008 & 367,3 \\
\hline 2009 & 374,8 \\
\hline 2010 & 374,0 \\
\hline 2011 & 375,9 \\
\hline 2012 & 407,7 \\
\hline 2013 & 428,2 \\
\hline 2014 & 435,3 \\
\hline 2015 & 470,9 \\
\hline 2016 & 460,6 \\
\hline 2017 & 443,2 \\
\hline 2018 & 431,7 \\
\hline
\end{tabular}

Наибольшее развитие рецидивная преступность получила в Дальневосточном федеральном округе (далее - ДФО): в 2018 г. коэффициент составил 908,1, т.е. в два раза выше, чем в среднем по стране. Более того, в 2018 г. в сравнении с предыдущим годом уровень рецидива в ДФО вырос на 27,6\% (в 2017 г. - 657,2). Такая динамика обусловлена в том числе территориальными изменениями ДФО, который в соответствии с Указом Президента РФ от 03.11.2018 № 632 пополнился новыми субъектами РФ - Республикой Бурятия и Забайкальским краем, ранее бывшими в составе Сибирского федерального округа [7]. Данные регионы традиционно относятся к числу наиболее рецидивоопасных: уровень рецидива в Бурятии - 872,3, в Забайкальском крае - 853,4 (по данным 2018 г.).

Как известно, состояние рецидивной преступности обусловливается общей криминологической ситуацией в регионе. Там, где высок уровень первичной преступности, коэффициенты рецидива выше. Между тем рецидивная преступность в ДФО характеризуется более высокими значениями, нежели общая преступность. Так, если интенсивность общей преступности в ДФО выше общероссийского коэффициента на 14,0\%, то рецидивной - на $110 \%$. Следовательно, можно говорить о повышенной рецидивной пораженности ДФО. Данное обстоятельство во многом связано с тем, что на востоке страны проживает большое количество многократно судимых, лиц, отбывших наказание и оставшихся здесь для дальнейшего проживания, что предопределяет высокий удельный вес лиц с антиобщественными установками, преступными взглядами и воззрениями [8. С. 279]. 
Таблица 5

Уровень общей и рецидивной преступности в Российской Федерации и федеральных округах (2018)

\begin{tabular}{|c|c|c|c|c|}
\hline & $\begin{array}{c}\text { Уровень } \\
\text { общей } \\
\text { преступности }\end{array}$ & $\begin{array}{c}\text { По отношению к } \\
\text { среднему значению } \\
\text { уровня преступно- } \\
\text { сти в России, \% }\end{array}$ & $\begin{array}{c}\text { Коэффициент } \\
\text { рецидивной } \\
\text { преступности }\end{array}$ & $\begin{array}{c}\text { По отношению к } \\
\text { среднему значе- } \\
\text { нию уровня реци- } \\
\text { дивной преступн-- } \\
\text { сти в России, \% }\end{array}$ \\
\hline $\begin{array}{l}\text { Российская } \\
\text { Федерация }\end{array}$ & 1355,9 & - & 431,7 & - \\
\hline $\begin{array}{l}\text { Центральный } \\
\text { федеральный } \\
\text { округ }\end{array}$ & 1147,2 & 84 & 283,0 & 66 \\
\hline $\begin{array}{l}\text { Северо-Западный } \\
\text { федеральный } \\
\text { округ }\end{array}$ & 1319,8 & 97 & 398,2 & 92 \\
\hline $\begin{array}{l}\text { Северо- } \\
\text { Кавказский фе- } \\
\text { деральный округ }\end{array}$ & 712,5 & 53 & 223,0 & 52 \\
\hline $\begin{array}{l}\text { Южный } \\
\text { федеральный } \\
\text { округ }\end{array}$ & 1270,5 & 94 & 374,3 & 87 \\
\hline $\begin{array}{l}\text { Приволжский } \\
\text { федеральный } \\
\text { округ }\end{array}$ & 1287,8 & 94 & 452,0 & 105 \\
\hline $\begin{array}{l}\text { Уральский } \\
\text { федеральный } \\
\text { округ }\end{array}$ & 1556,9 & 115 & 550,8 & 128 \\
\hline $\begin{array}{l}\text { Дальневосточный } \\
\text { федеральный } \\
\text { округ }\end{array}$ & 1907,0 & 140 & 908,1 & 210 \\
\hline $\begin{array}{l}\text { Сибирский } \\
\text { федеральный } \\
\text { округ }\end{array}$ & 2530,2 & 187 & 596,4 & 138 \\
\hline
\end{tabular}

Анализ рецидивной преступности будет неполным без изучения ее качественных характеристик - структуры. В структуре рассматриваемой преступности преобладают преступления небольшой тяжести - на их долю приходится $54,8 \%$, на преступления средней тяжести $-26,2 \%$; на тяжкие $15 \%$, на особо тяжкие - 4\%. По данному показателю рецидивная преступность повторяет структуру преступности в целом, в которой преступления небольшой тяжести также являются самыми распространенными: в 2018 г. их доля составила $44,3 \%$.

Как отмечалось выше, судимости за совершение умышленных преступлений небольшой тяжести не учитываются при признании рецидива, потому из него выпадает весьма значительная часть преступлений. Учеными, исследовавшими проблемы рецидива, отмечалось, что положение о неучете судимости за умышленные преступления небольшой тяжести (п. «а» ч. 4 ст. 18 УК РФ) при признании рецидива не отвечает принципу справедливо- 
сти. По их мнению, это «провоцирует увеличение количества профессиональных преступников, в особенности тех, кто совершает примитивизированные и системообразующие преступления. Следует, наоборот, последовательно продолжающуюся преступную деятельность, систематическое повторение преступлений небольшой тяжести (три и более раза) признавать разновидностью опасного рецидива преступлений» [9. С. 17].

Таблица 6

Удельный вес осужденных, признанных совершившими преступление при рецидиве, по отдельным преступлениям в общем объеме осужденных за данные преступления

\begin{tabular}{|c|c|c|c|c|c|c|c|}
\hline Преступление & & 2013 & 2014 & 2015 & 2016 & 2017 & 2018 \\
\hline \multirow[t]{3}{*}{ Кража } & Всего осужденных & 213909 & 198922 & 209617 & 199071 & 176643 & 164739 \\
\hline & $\begin{array}{l}\text { Осужденных, име- } \\
\text { ющих неснятые } \\
\text { и непогашенные } \\
\text { судимости на мо- } \\
\text { мент совершения } \\
\text { преступления }\end{array}$ & 99558 & 91602 & 89801 & 82931 & 82083 & 80211 \\
\hline & Доля, \% & 46,5 & 46,0 & 42,8 & 41,7 & 46,5 & 48,7 \\
\hline \multirow[t]{3}{*}{ Грабеж } & Всего осужденных & 40467 & 35754 & 33300 & 31516 & 29623 & 27385 \\
\hline & $\begin{array}{l}\text { Осужденных, име- } \\
\text { ющих неснятые } \\
\text { и непогашенные } \\
\text { судимости на мо- } \\
\text { мент совершения } \\
\text { преступления } \\
\end{array}$ & 19317 & 17013 & 15462 & 14472 & 14470 & 14256 \\
\hline & Доля, \% & 47,7 & 47,6 & 46,4 & 45,9 & 48,8 & 52,1 \\
\hline \multirow[t]{3}{*}{ Разбой } & Всего осужденных & 12028 & 11261 & 10583 & 9884 & 8973 & 7549 \\
\hline & $\begin{array}{l}\text { Осужденных, име- } \\
\text { ющих неснятые } \\
\text { и непогашенные } \\
\text { судимости на мо- } \\
\text { мент совершения } \\
\text { преступления }\end{array}$ & 5325 & 4949 & 4460 & 3981 & 3779 & 3328 \\
\hline & Доля, \% & 44,3 & 43,9 & 42,1 & 40,3 & 42,1 & 44,1 \\
\hline \multirow[t]{3}{*}{ Убийство } & Всего осужденных & 9343 & 9249 & 9067 & 8928 & 8028 & 7198 \\
\hline & $\begin{array}{l}\text { Осужденных, име- } \\
\text { ющих неснятые } \\
\text { и непогашенные } \\
\text { судимости на мо- } \\
\text { мент совершения } \\
\text { преступления } \\
\end{array}$ & 3067 & 2985 & 2824 & 2648 & 2381 & 2303 \\
\hline & Доля, \% & 32,8 & 32,3 & 31,1 & 29,7 & 29,7 & 32,0 \\
\hline \multirow{3}{*}{$\begin{array}{c}\text { Умышленное } \\
\text { причинение } \\
\text { тяжкого вреда } \\
\text { здоровью }\end{array}$} & Всего осужденных & 30213 & 28776 & 26893 & 25244 & 22630 & 20494 \\
\hline & $\begin{array}{l}\text { Осужденных, име- } \\
\text { ющих неснятые } \\
\text { и непогашенные } \\
\text { судимости на мо- } \\
\text { мент совершения } \\
\text { преступления } \\
\end{array}$ & 8335 & 8102 & 7248 & 6460 & 5948 & 5633 \\
\hline & Доля, \% & 27,6 & 28,2 & 26,9 & 25,6 & 26,2 & 27,5 \\
\hline
\end{tabular}




\begin{tabular}{|c|c|c|c|c|c|c|c|}
\hline \multicolumn{8}{|c|}{ Окончание табл. 6} \\
\hline Преступление & & 2013 & 2014 & 2015 & 2016 & 2017 & 2018 \\
\hline Незаконные & Всего осужденных & 108597 & 114078 & 114543 & 104018 & 102254 & 90876 \\
\hline $\begin{array}{c}\text { действия и на- } \\
\text { рушение правил } \\
\text { обращения с } \\
\text { наркотическими } \\
\text { средствами и } \\
\text { психотропными }\end{array}$ & $\begin{array}{l}\text { Осужденных, име- } \\
\text { ющих неснятые } \\
\text { и непогашенные } \\
\text { судимости на мо- } \\
\text { мент совершения } \\
\text { преступления }\end{array}$ & 32776 & 32432 & 31596 & 27110 & 27615 & 25506 \\
\hline веществами & Доля, \% & 30,2 & 28,4 & 27,6 & 26,1 & 27,1 & 28,1 \\
\hline
\end{tabular}

По виду преступлений в рецидивной преступности лидируют общеуголовные составы, прежде всего против собственности (42,7\%), против личности $(16,6 \%)$ и против здоровья населения $(11,9 \%)$ [10. С. 81$]$. При этом наибольшая доля ранее судимых наблюдается среди осужденных за грабеж $(52,1 \%)$, кражу $(48,7 \%)$, разбой $(44,1 \%)$ (табл. 6).

Высокий процент рецидива наблюдается у наркопреступников - 28-30\%, причем, как правило, это специальный рецидив, т.е. рецидив со стороны тех, кто ранее совершал однородные (тождественные) преступления [11. С. 28].

Статистика судимости в последние годы демонстрирует снижение абсолютного числа осужденных и одновременно увеличение в их числе доли ранее судимых лиц, имеющих неснятую и непогашенную судимость. Общая численность осужденных сократилась на $27,7 \%$, число ранее судимых в абсолютном выражении показало снижение на $10 \%$, однако их удельный вес в общем количестве осужденных вырос на 6,9\%. В 2018 г. число осужденных, имеющих неснятые и непогашенные судимости на момент совершения преступления, составило 231583 человека, или $35,2 \%$ от всех осужденных (табл. 7) [12].

Таблица 7

Численность осужденных и удельный вес ранее судимых лиц в период с 2006 по 2018 г.

\begin{tabular}{|c|c|c|c|}
\hline Год & $\begin{array}{c}\text { Число } \\
\text { осужденных }\end{array}$ & $\begin{array}{c}\text { Число ранее судимых лиц } \\
\text { (имеющих неснятую или } \\
\text { непогашенную судимость) }\end{array}$ & $\begin{array}{c}\text { Удельный вес ранее судимых } \\
\text { в общем числе осужденных }\end{array}$ \\
\hline 2006 & 909921 & 257310 & 28,3 \\
\hline 2007 & 916566 & 255953 & 27,9 \\
\hline 2008 & 914541 & 260028 & 28,4 \\
\hline 2009 & 882291 & 270218 & 30,6 \\
\hline 2010 & 836374 & 267164 & 31,9 \\
\hline 2011 & 782274 & 258301 & 33,0 \\
\hline 2012 & 739278 & 254279 & 34,4 \\
\hline 2013 & 735340 & 250245 & 33,6 \\
\hline 2014 & 719297 & 241764 & 32,7 \\
\hline 2015 & 734581 & 240067 & 30,9 \\
\hline 2016 & 740410 & 228450 & 32,2 \\
\hline 2017 & 697054 & 224115 & 35,2 \\
\hline 2018 & 658291 & 231583 & \\
\hline
\end{tabular}


Рост доли лиц, ранее совершавших преступления, с одновременным снижением общего числа лиц, выявленных за совершение преступлений и осужденных, свидетельствует о повышении уровня многократного, пенитенциарного, постпенитенциарного, особо опасного и опасного рецидива [10. С. 81].

В исследуемый период негативные изменения преступности нашли отражение и в составе осужденных к лишению свободы [13]. Среди осужденных выросла доля тех, кто осужден к лишению свободы третий и более раз. Если в 2007 г. их доля составляла 20,2\%, то в 2018 г. - 36,1\%, одновременно сократился удельный вес осужденных к лишению свободы впервые с 53,7 до $45,8 \%$ (табл. 8 ).

Таблица 8

Характеристика осужденных, которые осуждены к лишению свободы

\begin{tabular}{|l|c|c|c|c|c|c|}
\hline & 2007 & 2008 & 2009 & 2010 & 2011 & 2012 \\
\hline Впервые & 385197 & 390708 & 377891 & 336041 & 302891 & 263710 \\
\hline Второй раз & 186579 & 191143 & 190149 & 169653 & 147716 & 140004 \\
\hline Третий и более раз & 144651 & 152440 & 156123 & 188792 & 189019 & 181374 \\
\hline & 2013 & 2014 & 2015 & 2016 & 2017 & 2018 \\
\hline Впервые & 245546 & 247374 & 238549 & 240807 & 230368 & 210924 \\
\hline Второй раз & 129024 & 116291 & 106104 & 97792 & 91108 & 83707 \\
\hline Третий и более раз & 185368 & 187187 & 180085 & 180881 & 173540 & 166292 \\
\hline
\end{tabular}

Проведенное исследование позволяет сделать выводы о тенденциях развития рецидивной преступности, в числе которых следует отметить:

1) рост как абсолютных, так и относительных ее показателей;

2) увеличение в общем количестве выявленных преступников лиц, ранее совершавших преступления;

3 ) рост криминальной активности лиц, ранее совершавших преступления, но освобождавшихся от уголовной ответственности за предыдущие преступления;

4) высокую рецидивную пораженность отдельных регионов, в которых уровень рецидива в разы превышает среднероссийские показатели;

5) увеличение в числе осужденных удельного веса ранее судимых лиц, имеющих неснятую и непогашенную судимость;

6) ухудшение характеристик осужденных к лишению свободы, увеличение среди них многократно судимых лиц.

\section{Литература}

1. Данные ГИАЦ МВД РФ о состоянии преступности в России за январь-декабрь 2007 г., 2008 г., 2009 г., 2010 г., 2011 г., 2012 г., 2013 г., 2014 г., 2015 г., 2016 г., 2017 г., 2018 г. URL: https://xn--b1aew.xn--p1ai/Deljatelnost/statistics.

2. Прозументов Л.М., Шеслер А.В. Криминология (Общая часть) : учеб. пособие. Томск : Изд. Дом Том. гос. ун-та, 2017. 284 с.

3. О едином учете преступлений : приказ Генеральной прокуратуры РФ, МВД РФ, МЧС РФ, Минюста РФ, ФСБ РФ, Минэкономразвития РФ и Федеральной службы РФ по контролю за оборотом наркотиков от 29.12.2005 № 39/1070/1021/253/780/353/399 // Российская газета. 2006. 25 янв., № 13. 
4. Артемьев Н.С. Анализ рецидивной преступности - научная основа прогнозирования и планирования ее профилактики // Человек: преступление и наказание. 2012. № 1 (76). С. 81-84.

5. Репецкая А.Л. Современное состояние, структура и тенденции российской преступности // Вестник Омского университета. Сер. Право. 2018. № 1 (54). С. 151-156.

6. Бытко Ю.И. Институту освобождения от уголовной ответственности нет места в законодательстве // Вестник Саратовской государственной юридической академии. 2017. № 5. C. 182-190.

7. О внесении изменений в перечень федеральных округов, утвержденный Указом Президента Российской Федерации от 13 мая 2000 г. № 849 : указ Президента РФ от 03.11.2018 № 632 // Собрание законодательства РФ. 2018. № 45. Ст. 6923.

8. Ролик А.И., Романова Л.И. Наркопреступность: уголовно-правовые и криминологические проблемы / науч.ред. А.И. Коробеев. Владивосток : Изд-во Дальневост. унта, 2016. $448 \mathrm{c}$.

9. Армашова А.В. Проблемы рецидива преступлений и ответственности за него по уголовному праву России : автореф. дис. ... канд. юрид. наук. Рязань, 2006. 28 с.

10. Комплексный анализ состояния преступности в Российской Федерации и расчетные варианты ее развития : аналит. обзор / Ю.М. Антонян, Д.А. Бражников, М.В. Гончарова и др. М. : ВНИИ МВД России, 2018. 86 с.

11. Филиппова О.В. О рецидивной преступности в сфере незаконного оборота наркотиков // Наркоконтроль. 2018. № 1. С. 27-29.

12. Судебная статистика // Судебный департамент при Верховном Суде Российской Федерации. URL: http://www.cdep.ru/index.php?id=79\&item=2074

13. Статистическая информация Федеральной службы исполнения наказаний России. URL: http://fsin.su/structure/inspector/iao/statistika/Xar-ka\%20lic\%20sodergahixsya\%20v\%20IK/

Filippova Olga V., East Siberian State University of Technology and Management (UlanUde, Russian Federation)

\section{CRIMINOLOGICAL CHARACTERISTICS OF RECIDIVISM}

Keywords: recidivism, criminality, criminological characteristic.

DOI: $10.17223 / 22253513 / 38 / 9$

Recidivism is an indicator of the imperfection of the system of punishments, the practice of their execution, as well as the stability of anti-social attitudes of those who commit crimes.

The purpose of this study is to conduct a criminological analysis of recidivism in the Russian Federation (to determine the level, structure and dynamics) in the period from 2006 to 2018 and on this basis to establish trends in its development.

Criminological characteristic of recidivism includes quantitative and qualitative analysis of the totality of crimes committed by persons who have previously committed crimes, after the application of criminal law measures to them for previous crimes, as well as the totality of these persons themselves.

The study led to conclusions about an increase in both the absolute and relative indices of recidivism: the number of crimes committed by persons who had previously committed offences increased by 18.4 per cent in the period under study, and the recidivism rate increased by 15.3 per cent. The recidivism rate doubled from $13.9 \%$ in 2006 to $31.6 \%$ in 2018.

There has been an increase in the number of persons who had previously committed crimes, while the criminal activity of persons who were exempted from criminal liability for previously committed crimes on non-rehabilitation grounds has also increased among the detected offenders. 
Minor offences accounted for the largest proportion of recidivism: 54.8 per cent. Offences of medium gravity accounted for 26.2 per cent, serious offences for 15 per cent and especially serious offences for 4 per cent.

Recidivism was mainly represented by crimes against property: their share was $42.7 \%$; crimes against persons $16.6 \%$, and against public health $11.9 \%$. The highest proportion of those previously convicted of robbery was observed (52.1\%). High recidivism rate was also observed among drug offenders - $28-30 \%$, and, as a rule, it was special recidivism, i.e. recidivism by those who had previously committed homogeneous (identical) crimes.

Criminal record statistics during the reviewed period showed a decrease in the absolute number of convicts, while at the same time an increase in the proportion of those with an unexpunged and unexpunged criminal record. In 2018, the number of convicts with an unexpunged and unexpunged criminal record at the time of the offence was 231583 , or $35.2 \%$ of all convicts

Among those convicted, the proportion of those who have been sentenced to imprisonment for the third time or more has increased. Whereas in 2007 their share was $20.2 \%$, in 2018 it was $36.1 \%$. - At the same time, the share of first-time offenders decreased from $53.7 \%$ to $45.8 \%$.

\section{References}

1. The Ministry of Internal Affairs of the Russian Federation. (n.d.) Dannye GIATs MVD RF o sostoyanii prestupnosti v Rossii za yanvar'-dekabr' 2007 g., 2008 g., 2009 g., 2010 g., 2011 g., 2012 g., 2013 g., 2014 g., 2015 g., 2016 g., 2017 g., 2018 g. [Data of the GIAC of the Ministry of Internal Affairs of the Russian Federation on the state of crime in Russia for January-December 2007, 2008, 2009, 2010, 2011, 2012, 2013, 2014, 2015, 2016, 2017, 2018]. [Online] Available from: https://xn--b1aew.xn--p1ai/Deljatelnost/statistics.

2. Prozumentov, L.M. \& Shesler, A.V. (2017) Kriminologiya (Obshchaya chast') [Criminology (General part)]. Tomsk: Tomsk State University.

3. Russian Federation. (2005) On the uniform registration of crimes: Order No. 39/1070/1021/253/780 / 353/399of the General Prosecutor's Office of the Russian Federation, the Ministry of Internal Affairs of the Russian Federation, the Ministry of Emergency Situations of the Russian Federation, the Ministry of Justice of the Russian Federation, the Federal Security Service of the Russian Federation, the Ministry of Economic Development of the Russian Federation and the Federal Service of the Russian Federation for the Control of Drug Trafficking dated December 29, 2005. Rossiyskaya gazeta. 25th January. (In Russian).

4. Artemiev, N.S. (2012) Analysis of recidivism - the scientific basis of prognosis and planning for its prevention. Chelovek: prestuplenie i nakazanie. 1(76). pp. 81-84. (In Russian).

5. Repetskaya, A.L. (2018) The current state, structure and trends of Russian crime. Vestnik Omskogo universiteta. Ser. Pravo - Herlad of Omsk University. Law. 1(54). pp. 151156. (In Russian). DOI: 10.25513/1990-5173.2018.1.151-156

6. Bytko, Yu.I. (2017) Institute of absolute discharge has no place in legislation. Vestnik Saratovskoy gosudarstvennoy yuridicheskoy akademii. 5. pp. 182-190. (In Russian).

7. Russian Federation. (2018) On amendments to the list of federal districts approved by Decree No. 849 of the President of the Russian Federation dated May 13, 2000: Presidential Decree No. 632 dated November 3, 2018. Sobranie zakonodatel'stva RF-Legislative Bulletin of the Russian Federation. 45. Art. 6923. (In Russian).

8. Rolik, A.I. \& Romanova, L.I. (2016) Narkoprestupnost': ugolovno-pravovye i kriminologicheskie problem [Drug crime: criminal law and criminal problems]. Vladivostok: Far Eastern State University.

9. Armashova, A.V. (2006) Problemy retsidiva prestupleniy i otvetstvennosti za nego po ugolovnomu pravu Rossii [Problems of recidivism and responsibility for it in the criminal law of Russia]. Law Cand. Diss. Ryazan. 
10. Antonyan, Yu.M., Brazhnikov, D.A., Goncharov, M.V. et al. (2018) Kompleksnyy analiz sostoyaniya prestupnosti $v$ Rossiyskoy Federatsii $i$ raschetnye varianty ee razvitiya [Comprehensive Analysis of the State of Crime in the Russian Federation and Calculation Options for its Development]. Moscow: Ministry of Internal Affairs of Russia.

11. Filippova, O.V. (2018) On Recidivism in Illicit Narcotic Drugs Trafficking. Narkokontrol'. 1. pp. 27-29. (In Russian).

12. Judicial Department at the Supreme Court of the Russian Federation. (n.d.) Sudebnaya statistika [Judicial statistics]. [Online] Available from: http://www.cdep.ru/index.php? id=79\&item $=2074$

13. Statistical information of the Federal Penitentiary Service of Russia. [Online] Available from: http://fsin.su/structure/inspector/iao/statistika/Xar-ka\%20lic\%20sodergahixsya\%20v\%20IK/ 